\title{
Wildfires in the Atomic Age: Mitigating the Risk of Radioactive Smoke
}

\author{
Christine Eriksen
}

check for

updates

Citation: Eriksen, C. Wildfires in the Atomic Age: Mitigating the Risk of Radioactive Smoke. Fire 2022, 5, 2. https://doi.org/10.3390/fire5010002

Academic Editors: Alistair M. S. Smith and Stephen D. Fillmore

Received: 6 December 2021

Accepted: 24 December 2021

Published: 26 December 2021

Publisher's Note: MDPI stays neutral with regard to jurisdictional claims in published maps and institutional affiliations.

Copyright: (C) 2021 by the author. Licensee MDPI, Basel, Switzerland. This article is an open access article distributed under the terms and conditions of the Creative Commons Attribution (CC BY) license (https:// creativecommons.org/licenses/by/ $4.0 /)$.
Center for Security Studies, ETH Zürich, Haldeneggsteig 4, 8092 Zürich, Switzerland; christine.eriksen@sipo.gess.ethz.ch; Tel.: +41-44-632-6198

\begin{abstract}
This Perspective highlights the lingering consequences of nuclear disasters by examining the risks posed by wildfires that rerelease radioactive fallout originally deposited into the environment by accidents at nuclear power plants or testing of nuclear weapons. Such wildfires produce uncontainable, airborne, and hazardous smoke, which potentially carries radioactive material, thus becoming the specter of the original disaster. As wildfires occur more frequently with climate change and land use changes, nuclear wildfires present a pressing yet little discussed problem among wildfire management and fire scholars. The problem requires urgent attention due to the risks it poses to the health and wellbeing of wildland firefighters, land stewards, and smoke-impacted communities. This Perspective explains the problem, outlines future research directions, suggests potential solutions, and underlines the broader benefits of mitigating the risks.
\end{abstract}

Keywords: Chernobyl Exclusion Zone; climate change; fuel management; hazardous smoke; nuclear disasters; nuclear wildfires; radioactive contamination

\section{The Nuclear Wildfire Problem}

In April 2020, 34 years after the Chernobyl nuclear disaster, wildfires in the Chernobyl Exclusion Zone (CEZ) in Ukraine rereleased radioisotopes originally deposited into local ecosystems during the accident [1]. More than one thousand wildfires have burned in the CEZ since 1986, and the drifting, potentially radioactive, smoke is cause for international concern given the updraft caused by wildfires and the ability of smoke to travel far and wide $[2,3]$. The relatively undisturbed growth of vegetation in the forests and on former farmland in the CEZ, which have been uninhabited since 1986, has resulted in a fuel management problem [4]. Furthermore, up to $85 \%$ of the radioactivity is concentrated in the soil (with the remainder deposited in vegetation) [5]. Organic carbon-rich soil surface horizons, such as the Chernozems common in the region contaminated by the Chernobyl nuclear disaster [6-8], may burn intensely during dry seasons, becoming a serious potential source for smoke and hot particles. In an era where the linked effects of climate change and land management practices are increasing the frequency, intensity, and scope of wildfires internationally [9], smoke in general, and from radioactively contaminated sites in particular, poses a risk to wildland firefighters, land stewards, and smoke-impacted communities alike $[3,10,11]$. Given the half-lives of certain radioisotopes, this problem will not disappear in the lifetimes of all living generations [4].

Wildfires becoming the specter of the Chernobyl nuclear disaster is an extreme but not a standalone example of a significant yet little discussed problem of the Anthropocene-an epoch where anthropogenic disasters interact with earth system processes to produce unpredictable and, at times, unmanageable events [12,13]. This includes sites of nuclear accidents as well as atomic bombings and former nuclear weapons test sites. Another well-known example is the area contaminated by the 2011 Fukushima Dai-ichi nuclear disaster in Japan [14]. Other examples of wildfire-impacted sites include Maralinga-the former nuclear weapons test site in South Australia [15], and sites in the U.S., such as the Santa Susana Field Laboratory (SSFL) in California [16], the Nevada National Security Site [17], and the Los Alamos National Laboratory in New Mexico [18]. 
Each time firefighters and land stewards tackle wildfires in contaminated areas, they are exposed to contaminants that persist in the landscape long term because of the original nuclear disaster. Firefighters can reach the limit of what is considered a safe annual radiation dose over a "relatively small number of days" [4] (p.41). While radiation levels during a wildfire are not as high as they are during a direct encounter with a radioactive source, the cumulative effect of exposure to low levels of radiation over the career of a firefighter is unknown [11,19]. A radiological assessment of two sizeable wildfires in the CEZ in April and August 2015 measured exposure to radiation at above 1 millisievert (mSv) per year within the CEZ; outside the Zone and in the rest of Europe doses were much lower, "equivalent to a medical X-ray image at most" [20] (n.p.). For context, $100 \mathrm{mSv}$ per year is the lowest level of exposure at which there is clear evidence of an increased risk of cancer [21]. The uncertainty and the potential long-term consequences equate to a form of "slow violence" [22] - a type of violence that occurs out of sight and is not usually perceived or felt as violence.

Moreover, as argued by Eriksen and Turnbull [1], dose rates are not always the most useful measure for understanding the possible consequences of radioisotopes rereleased by wildfires [see also 11,18]. In areas where radiation spikes are recorded in proximity to a wildfire, microscopic pieces of radioactive material known as "hot particles" are readily aerosolized. The effects of hot particles are controversial in the scientific community, in part because the properties of hot particles make them difficult to measure, and in part because it is difficult to directly attribute the potential health damages of ingesting them [23]. If ingested, some scientists argue that these radioactive materials can settle in specific tissues in the body and deliver a concentrated dose of radiation to a small group of cells. Thus, although rare, hot particles may be very dangerous. There is concern that radiation risk models derived only from external exposure may not account for the risks associated with internally ingested hot particles. As such, radiation readings alone cannot account for the effects of exposure to radiation during wildfires.

Sensing radioactivity is also an embodied experience for firefighters who lack adequate monitoring and safety equipment [1,15] see also [24]. A firefighter at a station near the Chernobyl Nuclear Power Plant, described:

"I know when I am fighting a fire on radioactively contaminated ground-you get the heat just like an ordinary fire, but you get a tingling sensation too, like pins jumping all over your body. I don't know how bad it is for me, there's no medical testing afterwards, we just go and wash" quoted in [25] (n.p.).

However, not all firefighters report such embodied experiences. For some, it is the uncertainty of the perceived normalcy of the situation that is unhinging:

"When you go there, the forest, the trees, and the air are the same. Nothing tells you that the place is dangerous, only the device [Geiger counter] beeping" quoted in [19] (n.p.).

Such perspectives speak to the urgency of mitigating the risks and understanding the health consequences of nuclear wildfires.

\section{Potential Solutions and Future Research Directions}

Despite the known challenges and the known unknowns, there are tangible steps that can be taken to address the problem of wildfires rereleasing radioactive fallout. These steps require research as well as goodwill and cooperation across institutional, political, and geographical borders. It is therefore important to provide medical, political, cultural, and socioeconomic incentives for acknowledging and mitigating the risks.

1. Establish the geology, soil compositions, vegetation types, wildfire history, and associated land management issues at contaminated sites, and examine how these may be changing due to climate change and broader land use changes. These factors influence important dynamics, such as fuel load and flammability, the soil-to-plant radionuclide 
transfer factor, the potential of soil for rereleasing smoke and hot particles into the air, and particle leaching into the groundwater [26].

2. Develop an in-depth understanding of: (a) the movement and measurement of hot particles, (b) how likely people are to ingest them via airways, the skin, food, and drink when exposed to contaminated smoke, and (c) the potential short- and long-term health impacts. Such epidemiological research may be usefully connected to recent developments in aerobiology, which show wildfire smoke as a potential infectious agent that can carry viable microbes for long distances with other potential health repercussions, particularly for wildland firefighters [27-29].

3. Model where future smoke from contaminated areas is likely to travel, and prepare for the potential risks to downwind communities. The direction of dominant winds at certain times of the year, particularly during the fire season, is already a core part of wildfire management [30,31], and recent fire seasons have demonstrated the unequal consequences of drifting smoke on society more broadly [32]. Appropriate knowledge of soil properties (particularly soil organic carbon content and moisture), and hence soil type, also plays an important role in developing such predictive hazard models [11]. Soils with organic carbon-rich surface horizons are more likely to undergo intense burning than the desert areas of many nuclear weapons testing sites where soils usually lack organic matter, meaning smoke generation mainly comes from plant fuels in deserts.

4. To avoid a buildup of hazardous fuel levels in contaminated areas, prioritize forestry, scrubland, or grassland management via targeted land stewardship programs that value collaboration and knowledge sharing between diverse stakeholders, while ensuring the people performing the maintenance work have the personal protective equipment (PPE) suitable for the task.

5. Establish and share best practice protocols for firefighting in contaminated areas, and ensure wildland firefighters have the right PPE to avoid risky exposure such as that experienced by firefighters in the CEZ.

6. Equipment and fuel management come at a cost. Some agencies and regions have inadequate funding or political will to address the problem at hand. The pooling of expertise, collaborative efforts, and funding internationally is therefore important. Ensuring that wildland firefighting and land management agencies receive adequate funding to deal with nuclear wildfires should therefore be within the remit of international regulatory bodies and radiation protection organizations [21]. This will protect wildland firefighters, land stewards, and smoke-impacted communities alike from the lingering consequences of nuclear disasters.

More broadly, these steps will aid efforts to mitigate catastrophic wildfires and consequent $\mathrm{CO}_{2}$ emissions, thus curtailing a positive feedback loop where wildfires exacerbate climate change that exacerbates wildfires, and so on $[9,12]$. Reducing the risk of catastrophic wildfires also reduces the additional risk of contaminated particles being distributed via post-fire soil run-off into waterways and leaching into groundwater aquifers [26,33,34], and the broader pulmonary, cardiovascular, or microbial health implications associated with exposure to smoke particles $[3,10,27,29]$.

Lessons learnt may also prove valuable for the management of other types of contaminated sites that are vulnerable to wildfires and toxic smoke, such as areas polluted by chemical spills; noxious mixes of plastics, metals, paints, and other chemical substances in building materials and rubble; or forested regions where wildfires may trigger scattered wartime ammunition scraps.

Acting now on the risks of nuclear wildfires will mitigate the short- and long-term consequences on the environment, and on the people who live and work in these environments. The steps outlined above reflect a healthier and more holistic approach to wildfire management, which, at present, often relies on a reactive, triage system, despite advancements in data science solutions, predictive hazard and smoke propagation models, climatic scenarios, and firefighting equipment and technology. 
Funding: This research received no external funding.

Institutional Review Board Statement: Not applicable.

Informed Consent Statement: Not applicable.

Acknowledgments: Sincere thanks to Jonathon Turnbull and Jan Thiel for constructive conversations and comments on drafts. I am grateful to the audience of the California Fire Science Seminar series for stimulating conversations following the talk I gave on this topic in March 2021. Thank you also to the Fire editor-in-chief and the three peer reviewers for ensuring a robust publishing process.

Conflicts of Interest: The author declares no conflict of interest.

\section{References}

1. Eriksen, C.; Turnbull, J. Insure the volume? Sensing air, atmospheres and radiation in the Chernobyl Exclusion Zone. In Climate, Society and Elemental Insurance; Booth, K., Lucas, C., French, S., Eds.; Routledge: New York, NY, USA, 2022.

2. $\quad$ Evangeliou, N.; Balkanski, Y.; Cozic, A.; Hao, W.M.; Mouillot, F.; Thonicke, K.; Paugam, R.; Zibtsev, S.; Mousseau, T.A.; Wang, R.; et al. Fire evolution in the radioactive forests of Ukraine and Belarus: Future risks for the population and the environment. Ecol. Monogr. 2015, 85, 49-72. [CrossRef]

3. Reisen, F.; Duran, S.M.; Flannigan, M.; Elliott, C.; Rideout, K. Wildfire smoke and public health risk. Int. J. Wildland Fire 2015, 24, 1029-1044. [CrossRef]

4. Zibtsev, S.V.; Goldammer, J.G.; Robinson, S.; Borsuk, O.A. Fires in nuclear forests: Silent threats to the environment and human security. Unasylva 2015, 66, 40-51. Available online: https:/ / www.fao.org/3/I4447E/i4447e.pdf (accessed on 21 December 2021).

5. Hao, W.M.; Bondarenko, O.O.; Zibtsev, S.; Hutton, D. Vegetation fires, smoke emissions, and dispersion of radionuclides in the Chernobyl Exclusion. Zone Dev. Environ. Sci. 2009, 8, 265-275. Available online: https://www.fs.fed.us/psw / publications/4451 /psw_2009_4451-001_265-276.pdf (accessed on 21 December 2021).

6. FAO. Soil Map of the World_Europe; Food and Agricultural Organisation of the United Nations: Rome, Italy, 1992. Available online: https://www.fao.org/fileadmin/user_upload/soils/docs/Soil_map_FAOUNESCO/acrobat/Europe_V.pdf (accessed on 21 December 2021).

7. Kashkarov, L.L.; Kalinina, G.V.; Perelygin, V.P. A-particle track investigation of the Chernobyl nuclear power plant accident region soil samples. Radiat. Meas. 2003, 36, 529-532. [CrossRef]

8. Olga, K.; Tatiana, P. Land use in agricultural landscapes with chernozems contaminated after Chernobyl accident: Can we be confident in radioecological safety of plant foodstuff? Int. Soil Water Conserv. Res. 2019, 7, 158-166. [CrossRef]

9. Bowman, D.M.J.S.; Kolden, C.A.; Abatzoglou, J.T.; Johnston, F.H.; van der Werf, G.R.; Flannigan, M. Vegetation fires in the Anthropocene. Nat. Rev. Earth Environ. 2020, 1, 500-515. [CrossRef]

10. Reid, C.E.; Brauer, M.; Johnston, F.H.; Jerrett, M.; Balmes, J.R.; Elliott, C.T. Critical Review of Health Impacts of Wildfire Smoke Exposure. Environ. Health Perspect. 2016, 12, 1334-1343. [CrossRef] [PubMed]

11. Carvalho, F.P.; Oliveira, J.M.; Malta, M. Occupational and Public Exposure to Radionuclides in Smoke from Forest Fires-A Warning. In Occupational Safety and Hygiene VI, Proceedings of the 6th International Symposium on Occupation Safety and Hygiene (SHO 2018), Guimarães, Portugal, 26-27 March 2018; CRC Press: Boca Raton, FL, USA, 2018; pp. 125-130.

12. Eriksen, C. Fire. In Handbook of the Anthropocene; Wallenhorst, N., Wulf, C., Eds.; Springer Nature: Singapore, in Press.

13. Beck, U. Risk Society: Towards a New Modernity; Sage: New Delhi, India, 1992.

14. Kato, M.; Yamada, N.; Ichiki, T.; Kinomura, K.; Japan Nuclear Energy Safety Organization (JNES); International Atomic Energy Agency (IAEA). Evaluation of Radiation Dose by Wild Fire in Evacuation Zone after the Fukushima Accident. In Proceedings of the International Experts' Meeting on Radiation Protection after the Fukushima Daiichi Accident: Promoting Confidence and Understanding, Vienna, Austria, 17-21 February 2014. Available online: https://www-pub.iaea.org/iaeameetings/cn224p/ Session3/Ichiki.pdf (accessed on 21 December 2021).

15. Eriksen, C.; Ballard, S. Alliances in the Anthropocene: Fire, Plants, and People; Palgrave Macmillan Pivot: Singapore, 2020.

16. Kaltofen, M.; Gundersen, M.; Gundersen, A. Radioactive microparticles related to the Woolsey Fire in Simi Valley, CA. J. Environ. Radioact. 2021, 240, 106755. [CrossRef] [PubMed]

17. Seeman, M. Las Vegas may see smoke from Cherrywood fire at Nevada National Security Site. News 3 Las Vegas, 21 May 2021 Available online: https://news3lv.com/news/local/wildfire-burns-in-nevada-national-security-site-northeast-of-las-vegas (accessed on 17 November 2021).

18. Masco, J. The Nuclear Borderlands: The Manhattan Project in Post-Cold War New Mexico; Princeton University Press: Princeton, NJ, USA, 2006.

19. Bezpiatchuk, Z.; Pamment, C. Are forest fires unlocking radiation in Chernobyl? BBC News, 20 December 2020. Available online: https:/ / www.bbc.com/news/av/world-europe-55404164 (accessed on 17 November 2021).

20. Evangeliou, N.; Zibtsev, S.; Myroniuk, V.; Zhurba, M.; Hamburger, T.; Stohl, A.; Balkanski, Y.; Paugam, R.; Mousseau, T.A.; Møller, A.P.; et al. Atmospheric transport of radionuclides emitted due to wildfires near the Chernobyl Nuclear Power Plant in 2015 Geophys. Res. Abstr. 2016, 18, EGU2016-6034. Available online: https:/ / meetingorganizer.copernicus.org/EGU2016/EGU2016-60 34.pdf (accessed on 21 December 2021). 
21. IAEA. Radiation Protection and Safety of Radiation Sources: International Basic Safety Standards; International Atomic Energy Agency: Vienna, Austria, 2014. Available online: https:/ /www.iaea.org/publications / 8930/radiation-protection-and-safety-of-radiationsources-international-basic-safety-standards (accessed on 21 December 2021).

22. Nixon, R. Slow Violence and the Environmentalism of the Poor; Harvard University Press: Cambridge, MA, USA, 2013.

23. Goodhead, D.; Bramhall, R.; Busby, C.; Cox, R.; Darby, S.; Day, P.; Harrison, J.; Muirhead, C.; Roche, P.; Simmons, J.; et al. Report of the Committee Examining Radiation Risks of Internal Emitters (CERRIE); Committee Examining Radiation Risks of Internal Emitters: London, UK, 2004; ISBN 0-85951-545-1.

24. Creager, A. Human bodies as chemical sensors: A history of biomonitoring for environmental health and regulation. Stud. Hist. Philos. Sci. 2018, 70, 70-81. [CrossRef] [PubMed]

25. Evans, P. Forest Fires around Chernobyl Could Release Radiation, Scientists Warn. The Guardian, 26 April 2011. Available online: https:/ / www.theguardian.com/environment/2011/apr/26/chernobyl-radioactive-fires-global-danger (accessed on 17 November 2021).

26. IAEA. Handbook of Parameter Values for the Prediction of Radionuclide Transfer in Terrestrial and Freshwater Environments; International Atomic Energy Agency: Vienna, Austria, 2010. Available online: https://www.iaea.org/publications/8201/handbookof-parameter-values-for-the-prediction-of-radionuclide-transfer-in-terrestrial-and-freshwater-environments (accessed on 21 December 2021).

27. Kobziar, L.N.; Thompson, G.R. Wildfire smoke, a potential infectious agent. Science 2020, 370, 1408-1410. [CrossRef] [PubMed]

28. Kobziar, L.N.; Pingree, M.R.A.; Watts, A.C.; Nelson, K.N.; Dreaden, T.J.; Ridout, M. Accessing the life in smoke: A new application of unmanned aircraft systems (uas) to sample wildland fire bioaerosol emissions and their environment. Fire 2019, 2, 56. Available online: https:/ / www.mdpi.com/2571-6255/2/4/56 (accessed on 21 December 2021). [CrossRef]

29. Kobziar, L.N.; Pingree, M.R.A.; Larson, H.; Dreaden, T.J.; Green, S.; Smith, J.A. Pyroaerobiology: The aerosolization and transport of viable microbial life by wildland fire. Ecosphere 2018, 9, 1-12. Available online: https://www.fs.usda.gov/treesearch/pubs/57 391 (accessed on 21 December 2021). [CrossRef]

30. Prichard, S.J.; Povak, N.A.; Kennedy, M.C.; Peterson, D.W. Fuel treatment effectiveness in the context of landform, vegetation, and large, wind-driven wildfires. Ecol. Appl. 2020, 30, e02104. [CrossRef] [PubMed]

31. Keeley, J.E.; Syphard, A.D. Twenty-first century California, USA, wildfires: Fuel-dominated vs. wind-dominated fires. Fire Ecol. 2019, 15, 24. [CrossRef]

32. Simon, G.; Eriksen, C. The unequal social consequences of wildfire smoke in California. Bay Nature, 20 April 2021. Available online: https:/ / baynature.org/2021/04/20/the-unequal-social-consequences-of-wildfire-smoke-in-california/ (accessed on 21 December 2021).

33. Rhoades, C.C.; Chow, A.T.; Covino, T.P.; Fegel, T.S.; Pierson, D.N.; Rhea, A.E. The legacy of a severe wildfire on stream nitrogen and carbon in headwater catchments. Ecosystems 2019, 22, 643-657. [CrossRef]

34. Shaw, G.; Bailey, E.; Crout, N.; Field, L.; Freeman, S.; Gaschak, S.; Hou, X.; Izquierdo, M.; Wells, C.; Xu, S.; et al. Analysis of 129i and $127 \mathrm{i}$ in soils of the Chernobyl Exclusion Zone, 29 years after the deposition of 129i. Sci. Total Environ. 2019, 692, 966-974. [CrossRef] [PubMed] 